\title{
ИНДЕКС СТЕАТОЗА КАК МАРКЕР НЕАЛКОГОЛЬНОЙ ЖИРОВОЙ БОЛЕЗНИ ПЕЧЕНИ У ПАЦИЕНТОВ С СЕРДЕЧНОЙ НЕДОСТАТОЧНОСТЬЮ И САХАРНЫМ ДИАБЕТОМ 2 ТИПА
}

\author{
Диане М.Л. (Гвинея)
}

Индекс стеатоза печени, в настоящее время рассматривается как простой неинвазивный метод скрининга неалкогольной жировой болезни печени (НАЖБП) и предиктор ее прогрессирования. Наличие НАЖБП у пациентов с сердечной недостаточностью (CH) и сахарным диабетом (СД) способствует формированию худшего прогноза в отличие от пациентов без СД 2 типа (М. Е. Стаценко и др., 2016).

ЦЕЛЬ: оценить значения индекса стеатоза как маркера НАЖБП у пациентов с СН в зависимости от наличия СД.

МАТЕРИАЛЫ И МЕТОДЫ: В Исследование бЫли включены 79 пациентов С СН (52\% мужчин, средний возраст 72 11 лет), из них 40 (50,6\%) имели в анамнезе СД 2 типа, 39 (49,4\%) пациентов не имели СД. ИМТ

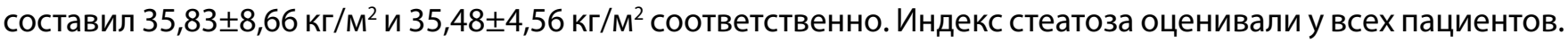
Значения индекса стеатоза 248 дБ/м, 268 дБ/м и 280 дБ/м (T. Karlas, et al. 2016) были использованы в качестве пороговых значений для диагностики НАЖБП легкой, средней и тяжелой степени соответственно.

РЕзУЛЬТАТЫ: значение индекса стеатоза было достоверно выше у пациентов с СД (312 552 дБ/М), чем у пациентов без СД $(291 \pm 49$ дБ/м) ( $<<0,05)$. Выявлена более высокая частота НАЖБП у пациентов с СД $22(27,8 \%)$, в отличие от пациентов без СД - 19 (24\%) соответственно, которая не достигла статистической значимости.

ВЫВОды: значение индекса стеатоза у пациентов с сердечной недостаточностью и СД было достоверно выше, чем у пациентов без СД по причине наличия НАЖБП. 